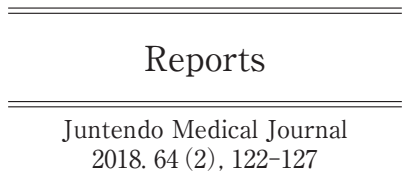

\section{Environmental Pollution and Related Diseases Reported in Japan: From an Era of "Risk Evaluation” to an Era of "Risk Management"}

\author{
OKIO HINO*1) 2), YAN YAN*1) 2), HIDEOKI OGAWA*3) \\ *1) Department of Pathology and Oncology, Juntendo University Faculty of Medicine, Tokyo, Japan, \\ *2) Department of Molecular Pathogenesis, Juntendo University Graduate School of Medicine, Tokyo, Japan, \\ *3) President, Juntendo University, Tokyo, Japan
}

Key words: environmental pollution, Four Major Pollution-Related Diseases, hazardous chemicals, asbestos, mesothelioma

\section{Introduction}

Japan's history of environmental pollution goes back to 1868 when the country initiated its industrialization -- "Fukoku Kyohei" (Enrich the Country, Strengthen the Military) under the Meiji regime. As Japan's economy went through periods of heavy industrial development and high economic growth the country also experienced environmental issues caused by mining, heavy industry, and the increased number of automobiles. Many environmental pollution-related diseases including asthma, Minamata Disease*, Itai Itai Disease ${ }^{* *}$, (see box under next section) and cancer have been recognized in Japan.

In this paper, we review Japan's history of environmental pollution and government responses and we advocate a shift in our stance toward environmental pollution-related diseases: from an era of "risk evaluation" to an era of "risk management".

\section{A brief history of environmental pollution in Japan}

1. Types of environmental pollution, major cases and related diseases

Japan has experienced two major types of environmental pollution: industrial pollution and automotive pollution, along with other environmental issues.

\section{1) Industrial pollution}

The Ashio Copper Mine Pollution Incident, which started in the 1880s in Tochigi prefecture, is considered the first serious industrial pollution case in Japan. Deforestation resulted from meeting the mine's timber demand and this, in turn, caused chronic flooding; sulfurous acid gas destroyed crops and harmed the health of local residents. Other mines, such as Besshi Copper Mine and Hitachi Copper Mine caused similar problems as well. Along with mining, the development of heavy industry also caused severe industrial pollution. Since coal was the main energy resource, soot and sulfur dioxide pollution remained serious until the mid-1960s, especially in the industrial centers of Mie prefecture, and the cities of Kita-Kyushu, Yokohama and Osaka.

Japan's economy experienced a period of high growth, from 1954 to 1972 , before the $1^{\text {st }}$ Oil Shock. During this period, Japan's economy continued to grow rapidly, while industrial pollution became a nationwide problem. Lawsuits were filed; pollutionrelated diseases were recognized; compensation

\footnotetext{
Corresponding author: Okio Hino

Department of Pathology and Oncology, Juntendo University Faculty of Medicine

2-1-1 Hongo, Bunkyo-ku, Tokyo 113-8421, Japan

TEL: +81-3-3813-3111 E-mail: ohino@juntendo.ac.jp

〔Received Feb. 14, 2018〕〔Accepted Apr. 26, 2018〕
}

Copyright (C) 2018 The Juntendo Medical Society. This is an open access article distributed under the terms of Creative Commons Attribution License (CC BY), which permits unrestricted use, distribution, and reproduction in any medium, provided the original source is properly credited. doi: 10.14789/jmj.2018.64.JMJ18-R02 
was paid to victims. Itai Itai Disease*, Minamata Disease $^{* *}$, Niigata Minamata Disease and Yokkaichi Asthma (caused by sulfur dioxide) were later called the "Four Major Pollution-Related Diseases" in Japan.

*Minamata disease is a toxic neuropathy caused by the ingestion of methylmercury compounds (as in contaminated seafood) and characterized by impairment of cerebral functions, constriction of the visual field, and progressive weakening of muscles (MerriamWebster's Medical Dictionary). It was first reported in Minamata of Kumamoto Prefecture in the year 1956, and later in Niigata Prefecture as well.

** Itai Itai Disease ( "it hurts-it hurts disease") is an extremely painful condition characterized by bone decalcification caused by poisoning following the ingestion of cadmium (MerriamWebster's Medical Dictionary). This name was given to the mass cadmium poisoning of Toyama Prefecture, starting around 1912. Only in 1955 did Dr. Hagino and his colleagues first suspect cadmium as the cause of the disease.

The Japanese economy continued to grow after the $1^{\text {st }}$ Oil Shock (1973), but entered a long period of low economic growth after the economic bubble burst in 1991. However, environmental pollution continued. In addition to the typical industrial water and industrial air pollution, there were two cases involving chemical carcinogens: (1) the Kubota Asbestos Disaster ("Kubota Shock") in 2005, caused by cumulative exposure to asbestos and (2) cholangiocarcinoma among offset printing workers in 2012, caused by cumulative exposure to dichloromethane/1,2-dichloropropane.

\section{2) Automotive and other environmental pollution}

As the number of vehicles grew from approximately 8 million in 1966 to more than 70 million in 1996, and then reached more than 80 million in 2016 (Ministry of Land, Infrastructure, Transport and Tourism), the total emissions of nitrogen oxides (NOx) and particulate matter (PM) increased dramatically. During a time, when industrial pollution was under control in the 1980s, photochemical smog became severe, along with noise issues. Suginami (Tokyo Metropolitan) photochem- ical smog of 1970 and low-frequency noise pollution of West Nagoya-Osaka Highway in the 1970s were among these issues.

Major environmental pollution cases and resulting diseases reported in Japan are listed below (Table-1, next page). The so-called Japanese "Four Major Pollution-Related Diseases" (Itai Itai Disease, Minamata Disease, Yokkaichi Asthma and Niigata Minamata Disease) are highlighted.

\section{Government responses to environmental issues}

Brought to the attention of the Japanese central government in the 1880s, the Ashio Copper Mine Incident is considered to be the first environmental pollution case in Japan. Victims in the Ashio Copper Mine vicinity suffered severe health problems and lost their farming and fishing resources mainly because of the sulfur dioxide and cadmium emitted during the process of copper refinery. Although the central government hesitated to directly intervene in the beginning, public awareness of environment protection grew nationwide.

As more mines, refineries, coal power plants, factories, and waste incinerators were built across Japan, farmers and citizens began to protest against the rising industrial pollution. As the number of vehicles increased, smog and noise issues increasingly affected people's daily lives. A large number of lawsuits were filed against corporations accused of producing pollution, and compensation was required. As responses, a series of regulations and laws were established as follows:

(1) Regarding industrial pollution

-Soot and Smoke Control Regulations (Osaka, 1932)

- Industrial Pollution Control Ordinance (Tokyo, 1949)

- Soot and Smoke Control Ordinance (Tokyo, 1955)

-Smoke and Soot Regulation Law (1962)

- Basic Law for Environmental Pollution Control (1967)

-Air Pollution Control Act (1968)

-Pollution-Related Health Damage Compensation Law (1973)

- Basic Environment Law (1993)

-Act on Asbestos Health Damage Relief (2006)

(2) Regarding automobile environmental issues

-Noise Regulation Act (1968) 
Table-1 Major Environmental Pollution Cases / Pollution-Related Diseases in Japan

\begin{tabular}{|c|c|c|}
\hline $\begin{array}{l}\text { Year of report/ } \\
\text { Incident period }\end{array}$ & $\begin{array}{c}\text { Major environmental pollution cases/ } \\
\text { Pollution-related diseases } \\
\text { (English) }\end{array}$ & $\begin{array}{c}\text { Major environmental pollution cases/ } \\
\text { Pollution-related diseases } \\
\text { (Japanese) }\end{array}$ \\
\hline 1880 s & The Ashio Copper Mine Pollution Incident & 足尾鉱毒事件 \\
\hline 1883 & Asano Cement Dust Pollution & 浅野セメント降灰問題 \\
\hline 1888 & Osaka Soot Pollution & 大阪煤煙問題 \\
\hline 1893 & Besshi Copper Mine Air Pollution & 別子銅山煙害 \\
\hline 1901 & Takasago Water Pollution & 高砂流毒問題 \\
\hline 1901 & Kosaka Mine Air Pollution & 小坂鉱山煙害 \\
\hline 1903 & The Osaka Alkali Incident & 大阪アルカリ事件 \\
\hline 1905 & Shisakajima Island Air Pollution & 四阪島煙害 \\
\hline 1907 & Hitachi Copper Mine Air Pollution & 日立鉱山煙害 \\
\hline 1914 & Sewage Pollution by Factories along the Aratagawa River & 荒田川工場排水 \\
\hline 1916 & $\begin{array}{l}\text { Air Pollution of Hydrogen Chloride Gas } \\
\text { (by the forerunner of Ajinomoto) }\end{array}$ & $\begin{array}{l}\text { 鈴木商店 (味の素) 排出の塩酸ガスによる農作 } \\
\text { 物被害 }\end{array}$ \\
\hline 1937 & Annaka Pollution & 安中公害 \\
\hline 1940 & Pulp Waste Pollution of the Ishigari River & 石狩川パルプ工場排水問題 \\
\hline 1955 & Itai Itai Disease & イタイイタイ病 \\
\hline 1955 & The Morinaga Milk Arsenic Poisoning Incident & 森永ヒ素ミルク中毒 \\
\hline 1956 & Minamata Disease & 水俣病 \\
\hline 1958 & Fishery Damages of the Edogawa River & 江戸川漁業被害 \\
\hline 1959 & Yokohama Asthma & 横浜ぜんそく \\
\hline 1961 & Yokkaichi Asthma & 四日市ぜんそく \\
\hline 1961 & Tobata (currently Kita-Kyushu city) Soot Pollution & 旧戸畑市煤煙問題 \\
\hline 1965 & Niigata Minamata Disease & 第二水俣病 \\
\hline 1967 & Well Water Cyanide Contamination & 八王子市井戸水のシアン污染事件 \\
\hline 1968 & Sewage Pollution by Ishihara Sangyo & 石原産業排水夕レ流し事件 \\
\hline 1968 & $\begin{array}{l}\text { The Kanemi Rice Bran Oil Poisoning Incident } \\
\text { (PCB Contaminated) }\end{array}$ & カネミ油症事件 \\
\hline 1969 & The Osaka Airport Noise Pollution Lawsuit & 大阪空港訴訟 \\
\hline 1969 & Yawata Steel Works Soot and Water Pollution & 八幡製鉄所煤塵水質污濁問題 \\
\hline 1969 & Miyata Yosui Water System Pollution & 宮田用水污濁問題 \\
\hline 1970 & Tagonoura Port Sludge Pollution & 田子の浦港へドロ公害 \\
\hline 1970 & Suginami Photochemical Smog & 杉並光化学スモッグ \\
\hline 1970 & Lead Poisoning (Ushigome-Yanagi, Shinjuku, Tokyo) & 新宿・牛込柳町鉛中毒 \\
\hline 1970s & Studded Tire-Generated Dust Pollution & スパイクタイヤによる粉塵公害 \\
\hline 1970s & $\begin{array}{l}\text { Low-Frequency Noise Pollution of } \\
\text { West Nagoya-Osaka Highway }\end{array}$ & 西名阪道路公害訴訟 \\
\hline 1971 & Toroku Arsenic Poisoning & 土呂久砒素公害 \\
\hline 1972 & Matsuo Arsenic Poisoning & 旧松尾鉱山ヒ素公害 \\
\hline 1973 & Sasagaya Arsenic Poisoning & 笹ヶ谷鉱害 \\
\hline 1973 & Hexavalent Chromium Pollution in Edogawa Ward & 江戸川区六価クロム廃棄事件 \\
\hline 1973 & High Level Mercury Poisoning & 鹿児島高濃度水銀污染 \\
\hline 1974 & Nagoya Shingansen Noise Pollution & 名古屋新幹線公害 \\
\hline 1974 & Chlorine Gas Leak by Nippon Aerosil & 日本アエロジル塩素ガス流出 \\
\hline 1975 & Soot Pollution by Kawasaki Steel Co. & 千葉市川崎製鉄のばい煙問題 \\
\hline 1975 & Naoetsu High Level Mercury Poisoning & 直江津高濃度水銀污染 \\
\hline 1975 & $\begin{array}{l}\text { The Teshima Incident (Illegal Dumping of } \\
\text { Industrial Waste in Teshima Island) }\end{array}$ & 豊島事件 \\
\hline 1978 & Nishiyodogawa Air Pollution & 西淀川公害 \\
\hline
\end{tabular}




\begin{tabular}{|c|c|c|}
\hline 1982 & Kadena Air Base Noise Pollution & 嘉手納基地爆音公害 \\
\hline 1982 & Kawasaki Air Pollution & 川崎公害 \\
\hline 1988 & Amagasaki Air Pollution & 尼崎公害 \\
\hline 1989 & Southern Nagoya Air Pollution & 名古屋南部大気污染公害 \\
\hline 1996 & The Tokyo Air Pollution Lawsuit & 東京大気污染訴訟 \\
\hline 1999 & The Tokaimura JCO Criticality Accident & 東海村JCO 臨界事故 \\
\hline 2000 & The Hikijikawa River Dioxin Contamination Incident & 引地川ダイオキシン污染事件 \\
\hline 2002 & $\begin{array}{l}\text { Environmental Damages caused by Coordinated Sediment } \\
\text { Flushing Operations in the Kurobekawa River }\end{array}$ & 黒部川連携排砂公害 \\
\hline 2002 & $\begin{array}{l}\text { Suginami Disease (Caused by Toxic Fumes from } \\
\text { a Waste Facility in Suginami, Tokyo) }\end{array}$ & 杉並病 \\
\hline 2003 & The Kamisushi Arsenic Incident & 神栖ヒ素事件 \\
\hline 2005 & The Kubota Asbestos Disaster ("Kubota Shock") & クボタ神崎工場アスベスト事件 \\
\hline 2009 & The Sannokawa River Dichloromethane Contamination Incident & 山王川水質污濁事件 \\
\hline 2011 & $\begin{array}{l}\text { Radioactive Contamination after } \\
\text { The Fukushima Daiichi Nuclear Power Plant Accident }\end{array}$ & 福島第一原子力発電所事故による放射能污染 \\
\hline 2012 & $\begin{array}{l}\text { Cholangiocarcinoma among Offset Printing Workers } \\
\text { (Caused by Cumulative Exposure to Dichloromethane/ } \\
\text { 1,2-Dichloropropane, Osaka) }\end{array}$ & 胆管がん問題 (大阪の印刷業者) \\
\hline
\end{tabular}

Source: Ministry of the Environment, Ministry of Economy, Trade and Industry, Ministry of Health and Welfare.

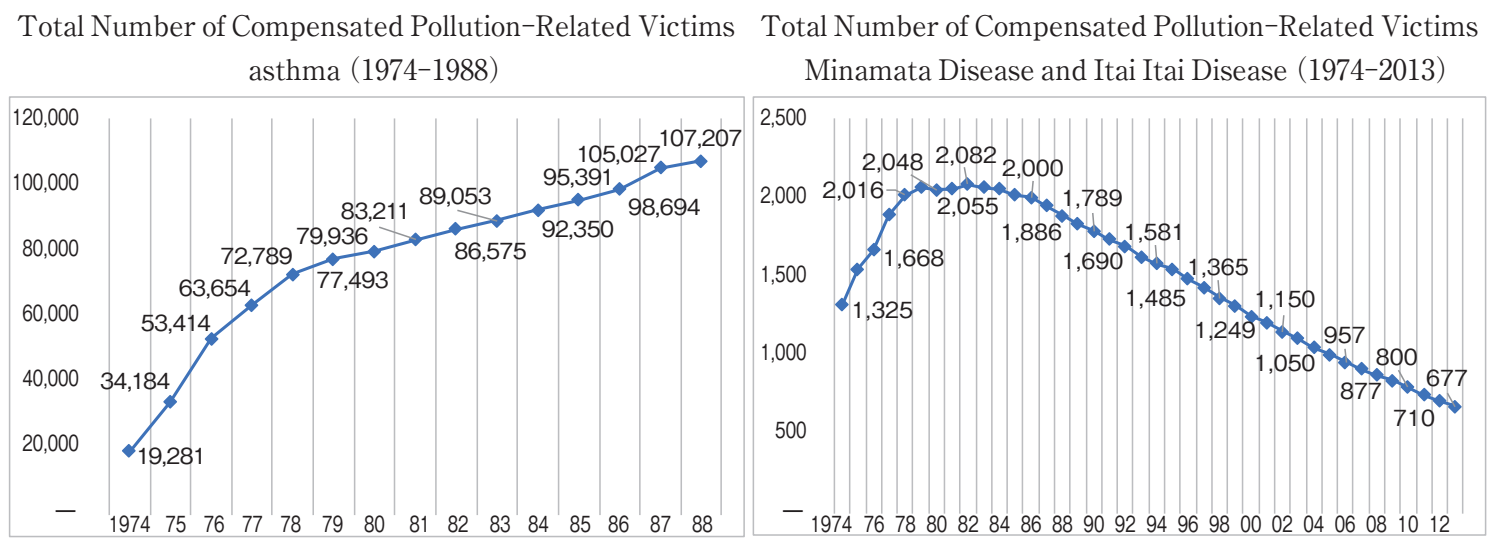

Source: Environmental Restoration and Conservation Agency of Japan

-Studded Tires Regulation Law (1990)

- The Law Concerning Special Measures for total Emission Reduction of Nitrogen Oxides and Particulate Matter from Automobiles in Specified Areas (The Automobile NOx/PM Law) (1992)

-Act on Regulation, etc. of Emissions from Non-Road Special Motor Vehicles (The "Off-Road Act") (2005)

Among the regulations and laws, the Japanese central and local governments enacted, the Pollution-Related Health Damage Compensation Law (1973) established clear measures to designate victims of environmental pollution and set up a compensation scheme accordingly. The above charts illustrate the total number of compensated victims of pollution-related Asthma, Minamata Disease, and Itai Itai Disease.

\section{On environmental pollution-related diseases reported in Japan: from an era of "risk evaluation" to an era of "risk management"}

As documented in the cases of the "Four Major Pollution-Related Diseases”, medical evidence was clear between the pollutants and the induced diseases: inhalation of soot and sulfur dioxide posed risks to the human respiratory systems; cadmium poisoning affected to the kidneys, skeletal and 
respiratory systems; and methylmercury poisoning threatened the nervous, digestive and immune systems.

While the "Four Major Pollution-Related Diseases" were being managed according to established industrial regulation and victim compensation laws in Japan, the so-called "Kubota Shock" occurred in 2005. Since then, the media outlets in Japan have shown noticeable interest and reported widescale "mesothelioma caused by asbestos". The Act on Asbestos Health Damage Relief was enacted in 2006. Through 2015, more than 10,900 people exposed to asbestos who developed mesothelioma, lung cancer, asbestosis, or diffuse pleural thickening (DPT), have been compensated (Ministry of the Environment).

This is truly ironic, in light of the fact that Japan was a pioneering nation in chemical-induced carcinogenesis research. In 1915, Katsusaburo Yamagiwa (1863-1930) accomplished a pioneering milestone in chemical (coal tar)-induced carcinogenesis by formative stimulation following the hypothesis of Virchow (1821-1902). How, then, should we approach such a critical problem? What lessons must we learn from these past mistakes in order that we do not make the same kinds of mistakes in the future?

Chemicals, such as asbestos, pose risks to human health. These risks are determined by the chemicalspecific hazardous properties and the extent of exposure to the chemicals. In terms of "hazardous properties”, International Agency for Research on Cancer (IARC) pointed out the higher risk of lung cancer and mesothelioma for laborers in asbestos mines. In addition, in 1987 IARC classified asbestos as a Group I carcinogen, defined as "exposure circumstance entails exposures that are carcinogenic" based on literature that found an increased risk of lung cancer for laborers working at factories making asbestos products.

In reality, "extent of exposure"--the length and amount of exposure deemed "dangerous" to cause cancer--involves some degree of vagueness. The fact that carcinoma takes long periods of time to develop after exposure (20 - 30 years) contributes to this vagueness. Nevertheless, to prevent asbestosrelated diseases, WHO recommended the cessation of all types of manufacturing with asbestos, replacing asbestos with safer substitutes, and taking measures to prevent exposure.

Concerning asbestos, our preventative measures and practical responses are decades behind, despite the fact that there was pathological and epidemiological evidence pointing to "risk". Ironically, asbestos import reached its peak in Japan in 1974, and only in 1995 was the most carcinogenic blue asbestos banned from production and use. By this time, however, many mesothelioma patients were already emerging. Although all types of asbestos and related products have been banned since 2006 (Ministry of Health, Labour and Welfares), exposure to asbestos is still possible. A typical occasion arises when an earthquake occurs, for example, where workers who clean the rubble face a risk of inhaling asbestos fibers emitted from old buildings.

Japan's asbestos tragedy was multiplied by factors including asbestos producers' inadequate risk awareness, researchers' deficiencies in communicating relevant risk information to third parties, and the government's delayed risk management and regulation. As the Japanese government and industry have worked collaboratively and banned all production and use of asbestos, we stand at the current position of effectively managing the risks, which involves "improving early diagnosis, treatment, social and medical rehabilitation of asbestosrelated diseases and establishing registries of people with past and/or current exposure to asbestos" (WHO).

In terms of early diagnosis and treatment, in studying rats genetically predisposed to develop kidney cancer, we found that the Erc gene product is often shed into the bloodstream at detectable levels as cancer progresses, thereby providing a possible method for blood diagnosis. Furthermore, because human ERC homologue (mesothelin) is expressed in the normal human mesothelium, including pleura, peritoneum, pericardium and tunica vaginalis, and it could be speculated that mesothelioma derived from the mesothelium should demonstrate overexpression of mesothelin, this method could possibly be used to diagnose mesothelioma. Indeed, we also reported that a diagnostic kit was being developed and researched. This is a real-life example of translational research.

Not only pertaining to asbestos, risk management of all hazardous chemicals requires open and transparent communication among the government, 
academia, industry and citizenry. By working together, the whole of society would be aware of the health risks of hazardous chemicals, eliminating the exposure to them, and providing effective early diagnoses and treatments to victims.

\section{Conclusion}

Japan's industrialization has come at a high price--severe environmental pollution--to society. Since the 1880s, approximately 60 environmental pollution incidents have occurred across Japan. Pollution-related diseases such as asthma, Minamata Disease, Itai Itai Disease and mesothelioma have been recognized. The Japanese government has consistently disclosed related information and acknowledged its responsibility in providing relief to victims. Indeed, a significantly large number of victims have been compensated.

By the mid-1950s, there were still doubts about the scientific evidence for causal linkage between pollutants and diseases. However, research on pollution-related diseases, carcinogens, and environmental carcinogenesis have progressed greatly since then. The reason we are dealing with asbestosinduced mesothelioma and lung cancer in the 21th century is partially due to the inadequacy of communication among researchers, the government, industry and the citizenry.

To avoid these mistakes in the future, there must be an approach that includes exchange, evaluation and management of risk information. For this to be effective, there needs to be an officially chartered organization to air concerns and build consensus across society. This organization would bring not only the government, but also academia, industry and labor, as well as consumer groups. Regarding environmental pollution and related diseases reported in Japan, we're moving from an era of "risk evaluation" to a new era of "risk management".

\section{References}

1) Environmental Restoration and Conservation Agency, The Air Pollution History of Japan, https://www.erca.go. $\mathrm{jp} /$ yobou/taiki/rekishi/07.html

2) Environmental Restoration and Conservation Agency, The History of Environmental Issues, https://www.erca. go.jp/yobou/taiki/kangaeru/history/01.html

3) Environmental Transport Policy Division, Environmental Management Bureau, Ministry of the Environment, Law to regulate Vehicle Exhaust in Japan, June 2015.

4) Japan Environmental Management Association for Industry, Management of Poisonous Chemical Materials, 2003. http://www. meti. go. jp/policy/recycle/main/3r_ policy/policy/pdf/text_2_1_a.pdf

5) Ministry of the Environment, Minamata Disease Archives. http://www. nimd. go. jp/archives/english/ tenji/a_corner/a01.html

6) International Agency for Research on Cancer, Monographs on the Evaluation of Carcinogenic Risks on Human.

7) The World Health Organization, Preventing Disease through Healthy Environments, 2010. http://www.who. int/ipcs/features/10chemicals_en.pdf 